\title{
Branding with Vlogs, Factor Affecting Their Success
}

\author{
Kanza Khalid (Corresponding author) \\ Research Scholar \\ Karachi University Business School, University of Karachi, Pakistan \\ E-mail: Kanzakhalidmascom@gmail.com \\ Dr. Danish Ahmed Siddiqui \\ Associate Professor \\ Karachi University Business School, University of Karachi, Pakistan \\ E-mail: daanish79@hotmail.com
}

Received: Feb. 24, 2019 Accepted: March 15, 2019 Published: April 16, 2019

doi:10.5296/bmh.v7i1.14402 URL: http://dx.doi.org/10.5296/bmh.v7i1.14402

\begin{abstract}
This study examines the culture of video blogging - its rhythm, language, and communication style and links its use to brand promotion and buying decisions. Specifically, we analyze factors which help in the success of Vlogs like its positioning in the viewer's mind, endorsement by celebrity, Ethical considerations, Benefits, and its Features. And then investigated how Vlog affect Brand Promotion and customers buying decisions. Quantitative research was carried out through the use of a questionnaire and collecting data of 212 respondents from Karachi. This study focused on Vlogs posted on YouTube Channel. Confirmatory factor analysis and structural equation modeling were used to analyze different variables. The result shows a strong and significant effect of factors such as Appeals, feature, ethical consideration and celebrity on Vlogging. Furthermore, strong evidence found that supported consumer buying decision and brand promotion is also influenced through Vlogs. Hence Vlog could be a major factor helping in building brands. Hence, this proves that Vlogger of Pakistan does not just life earn through it or gain fame and advantages in their daily, but they can also be part of branding strategies that are taking place through Vlogs.
\end{abstract}

Keywords: Vlogs, YouTube, celebrity endorsement, channel, brand promotion, consumer purchase decision, brands, communication style, confirmatory factor analysis, structural equation model 


\section{Introduction}

Vlogs are a form of self-introduction on the Internet and variations like video blogs (Vlogs) have expanded with the support of sites like YouTube. Vlog posts consist of creating a video of yourself or an event, uploading it to the internet, and publishing it within a post on your blog. However, it doesn't have to be that restrictive. People make Videos in which they provide a review about the product and their Instant feedback right on the spot, and many different companies approach the renowned face of the society to promote their product in a large sum of the audience.

Safko Lon (2012).

As of late Vlogging has turned into most searching plat foam everywhere throughout the world. Vlogging alludes to video blogging where individuals sit behind their cameras and discuss everything they want to, and afterward, they post what they have recorded to social video people. Individuals with various ages, nationalities, and interests take part in this all over the world. It gives individuals the chance to convey what they know something new about the product and services and what other person wants to know. It likewise empowers individuals to influence others by clarifying their thoughts and confusion related to anything and make them aware about the recent happening, it helps the viewers to ask more about the brand and its usage which they don't know ever before. Miles Jason. (2014).

As YouTube's trademark explains One can now "communicated yourself" (Garfield, 2006).

\subsection{Background}

The system of media has changed in the postmodern world. The shift from professional-made entertainment into more of a part-time created content is clearly observable in the today era of social media and platforms such as YouTube (SerranoPuche, 2017). Television, movies, and books as a form of entertainment have gotten competitors in the form of Instagram, blogs, and vlogs, media the digital natives of new generation use it in their everyday life. The time they spent watching television has decreased and the amount they spent online has increased (Serrano-Puche, 2017).

YouTube, as a channel is growing its status, as every minute over 400 hours of videos, is uploaded to YouTube (Statista, 2016). The fact that the YouTube channel is rated as the second most popular search engine (after the owner of the channel, Google), shows that not only there is a great deal of content but the audience is there searching and watching the content (Statista, 2016), thus being of high importance for the study. The content is provided not only by companies and professionals but also an amateur - the influence of the channel is that anyone can post content as it brings out unique content but also authentic at the same time.

The YouTubers, vloggers, are growing rapidly, the number of views and subscribers they have hence increased their numbers day by day. The most well-known vlogger, PewDiePie, has over 54 million subscribers and over 3000 videos (23rd March 2017) (YouTube, 2017). 
Ellen Franssen (2015) found the following chapter will elaborate on the results found in the analysis of the YouTube data collected from the three British beauty vloggers. After coding and organizing the data into themes, the following findings will attempt to give more insight into communication practices of beauty vloggers and how they relate to building a brand. In looking into communication strategies by the three beauty vloggers, the two research questions guided the analysis. As successful customer engagement is an essential feature to the building of a brand, and of high importance before persuasive communication strategies come into play, the first findings will be mainly related to the answering of the sub-question of how popular beauty vloggers use YouTube to engage with their fans. However, this first theme cannot be seen separately from the other themes found related to persuasive communication strategies. In the end, a total of three key themes related to communication strategies by the beauty vloggers have been found: fan engagement, online opinion leader and promotion. It had several limitations. First of all, because of the selection criteria leading to the choice of the three most successful beauty vloggers of the United Kingdom with data from 2013, several other factors have been excluded. First of all, by only focusing on the three most successful beauty vloggers, results might not be representable for strategies employed by lesser-known beauty vloggers. Secondly, the choice has been made to focus this research on beauty vloggers in specific. This has been done because the beauty vlog makes up a large portion of video content on YouTube and the way in which their video content revolves around the promoting and discussing of corporate products. In this paper, not only beauty Vlogger is focused, but also all Vloggers who want to start their own business either it is travel vlogs, educational vlogs, entertainment vlogs, or others. Secondly, many different factors explain which help in building a brand like Appeals with engaging the customer, ethical consideration attitude of the Vlogger towards their audience, features through which customer attract forcefully, brand promotion to promote it to a maximum number of audience and celebrity use for endorsement purpose.

In another study Zaitceva Elizaveta (2012) the result shows, literature review, quantitative and qualitative data collection proved four hypotheses: Entertainment, Informativeness, Interactivity, and Engagement. This research contributes to the understanding of what are key elements in creating successful video advertising on YouTube. As a result, all four hypotheses were significantly important in creating adverting on the platform on elements of video advertising on YouTube that are affected. Results showed that Entertainment, Storyline, Appropriate music, Colors, and Humor seems to be major features impacting Vlogs. However, this research focused on elements which are the key in creating a video but not mentioning those that focus on brands.

Moreover, no such studies were undertaken for Pakistan, Pakistan is a relatively new market for Vlogs as YouTube was banned in Pakistan for a long time and people were not aware of Vlogs and how to earn through social platforms. Now with changing trends youngster of Pakistan making their own YouTube channels. 


\section{Macrothink}

\subsection{Aims and Objectives}

The main aim of the research is to find out the impact of positioning in the viewer's mind, endorsement by celebrity, Ethical considerations, Benefits and its Features on the success of Vlogging. Secondly, how Vlogs impacts Brand Promotion and customers buying decisions. Hence, it will show how a video blog can help to build a brand and impact consumer engagement in social media. The goal of the project is to determine the possibility of a video blog channel as a branding tool with real-time online user engagement involvement.

\subsection{Significances}

This research will help so many youngsters even those people who want to start their own business online, for those who want to utilize their spare time by making videos on YouTube channel for branding purpose, Many companies approach Vloggers who have a high number of subscriber to promote their brand just to earn more money comes under brand promotion, Through attractive visual consumer appeal and buy it.

\subsection{Research Questions}

Which factors help in the success of Vlogs and how they impact buying behavior and brand?

\subsection{Definitions}

\subsubsection{Appeals}

Appeals made by Vlogger via using YouTube to sell out more products. The power of arouse a sympathetic response (Merriam, 1828).

\subsubsection{Brand Promotion}

Use to promote the brand through Vlogs. Promotions refer to the entire set of activities, which communicate the product, brand or service to the user. The idea is to make people aware, attract and induce to buy the product, in preference over others (Odhiambo, 2012).

\subsubsection{Celebrity}

Celebrity endorsement use to attract the audience. "Celebrity" is also defined by scholars as a practice, a method of attracting public attention and packaging an individual as a product. With this definition, the act of celebrity is turning a person into a consumable commodity that can then be advertised and consumed by the public (Gabler, 2010).

\subsubsection{Ethical Considerations}

An accumulation of values and principles that address questions of, what is good or bad in human affair.

\subsubsection{Features}

The main feature of Vlog is visual communication which is effective in catching the attention of the people. 


\subsubsection{Consumer Buying Decision}

People made their purchase after saw the reviews on YouTube that how much benefit the product. Consumer Buyer Behavior: "the buying behavior of final consumers; individuals who buy goods, and services for personal consumption. All of these final consumers combine to make up the consumer market" (Armstrong \& Kotler, 2003).

\section{Literature Review}

\subsection{Vlogging}

A vlog is a very personal video. A typical vlog is a single person, looking directly at a camera, viewable only from the waist (or more often shoulders) up. A vlog allows the viewer to take in non-verbal communication such as facial expression or gestures that build this trust and rapport more easily (Hansen, 1998).

Video can aid communication by adding social presence, a term originally coined and defined as the quality of being present when a communication medium is used. Social presence theory suggests that increased richness of the communication medium leads to increased social presence different communication media have varying degrees of social presence. For example, video, with its greater ability to support visual cues such as body language and facial expressions, generates a greater sense of social presence than audio alone (Roussel \& Gueddana, 2007).Text-based communication, like email, is not as effective as the telephone and in person communication for maintaining personal relations (Cummings, Butler \& Kraut, 2002). Video-based communication allows for greater social presence than email or the telephone because the audio and visual elements combined increase communication richness. Users benefit because video channels allow them to communicate in a more natural way resembling in-person communication (Bruce, 1996).

The main advantage of Vlogging its help in brand promotion and consumer buying decision whereas its greatest disadvantage is because of so many competitors in the market brand image vanishes and people switch towards another one where they find out good offerings (Fatima Sarwar et al., 2014).

\subsection{Brand or Celebrity Endorsement}

It seems that once a celebrity becomes famous and popular, he or she instantly appears in an ad and sometimes several at the same moment.'(Fleck, Korchia, \& Le Roy, 2012). Khatri (2006) studied that Celebrity Endorsement is the promotion strategy to attract customers and promote the brand and analyzing the current market. Hollensen and Schimmelpfennig (2013) explain the strength of Celebrity endorsement by appearing in the advertisement, a celebrity forms anassociationwiththe brand that he or she would not be associated with otherwise. Celebrity endorsements can exist in numerous forms, including sponsorship endorsements (e.g. Nike sponsoring Roger Federer), co-branded products (e.g. Lady Gaga for MAC make-up) and for testimonials (e.g. Katy Perry and Justin Bieber share their experiences with Proactive). Today, celebrity advertising has become one of the most popular advertising strategies, with around one in five TV advertisements featuring a celebrity 
globally (Hollensen \& Schimmelpfennig, 2013). Despite its prevalence, little is known about the effects of featuring a celebrity in advertising, and under what conditions the inclusion of this design element enhances or detracts from advertising effectiveness help in selling out more product, authentic reviews, generate more public, using Celebrity help in generating more revenues and help in engaging the audience (Carroll, 2008). Amos, Holmes, and Strutton (2008) explain the drawback while featuring celebrities may offer the aforementioned benefits, the potential risks alsoneed to be considered. These risks include having little control over a celebrity's personal life or other endorsement activities, particularly scandals and conflicts that may impact negatively upon the brand. The high cost of acquiring talent, which can range from $\$ 10,000$ to many million dollars (Chown \& Carter, 2012). Another concern, raised in the celebrity effectiveness research literature, is that the presence of a celebrity may overshadow take attention away from the primary brand being advertised (Evans, 1988).

\subsection{Consumer Buying Decision}

Customer buying is the procedure of how people select, purchase, use, and discard merchandise to fulfill their requirements and needs. People purchase the product to satisfy their need and fulfill their wants for that purpose they use social media plat foams in today technological advancement era Kotler and Keller, (2016). The relationship of consumer buying decision with Vlog are strongly relatedto each other, People influence through Vlogger in making their purchase decision by checking the reviews through Videos which help them in choosing a correct brand. Buyers have numerous requirements at some random time which turn into a rationale People buy unintentionally there impulsive buying behavior allow manufacturers to establish new products/brands. The best-known hypothesis of human inspiration is one of Abraham Maslow Solomon (2013). His premise of the hypothesis is that human needs are organized in an order from most to slightest squeezing. Individuals will initially endeavor to fulfill their most imperative need and after that move to the following stage.

\subsection{Appeals}

An influencer is someone who has a huge number of followers on several platforms with strong opinions which others base their opinions on. Influencer is a public figure on Social Media having thousands or millions of followers. Chow (2012) According to Miller, YouTube is a social networking podium and where everyone uploaded a video that will receive more views if the creator fully participates in the YouTube community by interacting and responding to the comments of the YouTube fans. The fans will notice the creator's presence on the channel and will come back more frequently to be able to interact with him/her. Being an active viewer and commenting on other channels will also help to grow one's presence on the platform, interact and look for other channels that have similar content. This has a 15 consequence that more people will find the vlogger's channel. Engaging with the viewers takes time and effort but it will create loyalty and a long-lasting relationship with the audience. The Appealing features which arepresented by Vlogger on YouTube channel help in grasping the audience attention. The strength of appealing it increases subscribers on 
YouTube channel (Miller, 2009).

\subsection{Brand Promotion}

Promotion is used to reference short-term marketing tactics such as sales and discounts as well as the overall promotion aspect of your marketing mix. (Christodoulides, 2009).

The relationship between brand through Vlogs has greater significance, Vlogs help in developing Brands many companies and sometimes they sponsor famous Vlogger who use their product in the video to attract audience, most of the new Vlogger who want to start their business establish their own brand and promote it and post it on Instagram stories where a largenumber of people easily see the reviews and detailed mention in the YouTube. The advantages of brand promotion it helps in selling out the product easily, attract a large number of people at once, help in establishing brand loyalty, develop customer relationship, so much brand promotion lose the impact of the message, People do not remember the message for so long. (Christodoulides,2009).

\subsection{Ethical Consideration}

Kirill (2001) thinks that YouTuber's honesty and ability to share personal thoughts is something that drives the audience to watch the content and motivates to subscribe to channels. In theory, this phenomenon can be supported by Bandura's explanation of the social cognitive theory. Audience's behavior and desire to follow specific content is shaped by influences of Vloggers and their channels Bandura, Albert (2001) The question "What is your motivation to watch YouTube" turned out to be a tricky one to answer for many of the many questions. The great answer that we receive the respect Vlogger give to the people shows their ethics towards handling their audience, another factor they are problem solver they provide the solutions and also tell different alternatives if people find out the difficulty in understanding it. The strength of Ethical consideration generates loyalty among the customers, people feel trustworthy but that Vlogger who all the time available to their subscriber will be underestimated and face out negative comments (Kirill, 2001).

A video blogger performs the role of a model because of his or her behavior, for those viewers who actively follow him. Content producer is using a media platform to spread his ideas and personal opinion amongst followers and people follow them because of their down to earth nature, which creates specific beliefs and judgments over a wide area. The more popular a Vlogger is, the more chances he has to be heard by a large audience and to perform as a model and motivational role model for his audience. Albert Bandura explains why modeling is significant in the process of media consumption and what are the effects and consequences of following a role model. Amongst other functions, Bandura mentions motivation, best reward, inhibition, value shaping and behavior as the most common grounds for content sharing (for bloggers) and consumption (for viewers).Bandura (2001) There are many ways YouTube can be used by a community of audiences, e.g. for motivation, best rewards, sharing opinions and creating new common experiences while watching and receiving information, giveaways, participating in contest, winning and Vlogger nature Mabillot (2007) The behavior of you tubers is considered as one of the most important acts in 


\section{Macrothink}

Business and Management Horizons

ISSN 2326-0297

2019, Vol. 7, No. 1

YouTube watching process Iversen (2009). According to Jones, Vlogger behavior or attitude helps them in building and generating their audience ref. in Strangelove 2010).

\subsection{Features}

Recently, there has been a wide significance in the visual aspects of communication (Barnhurst, Vari, Rodriguez, 2004; Barnhurst \& Quinn, 2012; Müller, 2007, 2008; Machin, 2014; Fahmy, Bock, \& Wanta, 2014). Consequently, there is a need to reflect on what it means claiming that society is increasingly visual (Machin, 2014). New information technologies affect media culture and the way images are used (Becker, 2004; Jenkins 2006), and the visuals have become a big part of our daily life, especially on the internet and in social media Fahmy et al., 2014; Adami \& Jewitt (2016). The digital image form has changed people's relationship, and by digital images, we memorialize social and organizational life Davison, McLean, Warren (2015). According to previous research, the role of practitioners is changing and they require more competencies to be successful in their communication roles Zerfass et al., (2007), (2013) in Tench \& Moreno, (2015). A factor that might cause changes in the practice of communication professionals is participation through social media.The strength of visual communication help in understanding the Vlogger idea and its product/brand. The weakness of the impact of nonverbal communication does not last for long as compared to verbal communication. (Falkheimer \& Heide, 2014).

\section{Conceptual Framework}

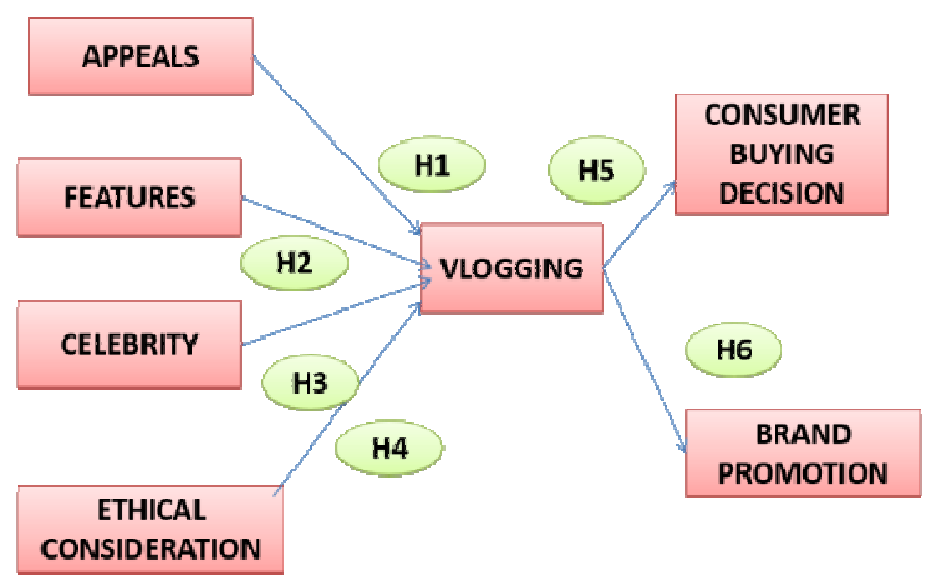

Figure 1. Research model

\subsection{Hypothesis}

H1 = Appeals made by Vlogger on YouTube channel have a positive effect on vlogs as that it grasps the customer attention.

$\mathrm{H} 2$ = Celebrity use as a medium to sell out the product on YouTube have a positive effect on vlogs. Through celebrity endorsement, many people buy the product by using the famous 
celebrity faces which help them in earning more money.

H3 = Ethical considerations have a positive effect on vlogs. They have a huge impact on the viewer's personality, through which they forcefully motivated to watch the Vlog. The respect is given by the Vlogger impressa lot of people to follow them on a daily bases or subscribe to their channel.

$\mathrm{H} 4=$ Features of Vlog which is visual and best reward have a positive effect on vlogs as these two items attract the view and force them to click on the recommended page or YouTubechannel, many people watch YouTubers just to win gifts and pass their free time by watching their videos which comes under visual communication attraction.

H5 = Vlogs affects Consumer buying decision. Because in today era mostly people buy online and before they want to go and purchase an item they surely search out the reviews by the people which help them in buying products.

H6=Vlogs affects Brand promotion. YouTube channels are made to promote the brands either they are sponsored by companies or establish by YouTubers own, brand promotion through Vlogs help in making easy money.

\section{Social Media Channel}

\subsection{YouTube}

YouTube is an online video sharing stage and nowadays it is a champion among the most visited locales on the web. Appropriate around $33 \%$ of people on the planet are enlisted in YouTube and these people make a billion in hours consistently, creating billions of subscriber. Videos are posted by different YouTube channel holders through which they entertain and provide knowledge to the customer YouTube (2017), Kelly David (2016).

\subsection{Facebook}

Facebook is the best communication platform around the world with pretty much two billion customers for every month, according to Facebook estimation. Facebook gives an individual a customer profile, business open pages on which customers may click 'like' to purchase in and gather systems for both private and open use. Cohen David (2017).

Facebook has progressed with new functionalities and organizations having been included once in a while. Nowadays it is functional for customers to do everything on Facebook. People can blend and talk with partners, families, and partners who are also Facebook users by methods for Facebook through comments and messenger. They can in like manner examine news articles, watch accounts or see photos of brands' pages that they seek after; in addition, they watch chronicles and view photos of individual people and enormous names or any substance on the all-inclusive community or groups in facebook. Kelly David (2016), Lafferty Justin (2017), Smith Kit (2016).

\subsection{Instagram}

Instagram is a photo and video sharing long range relational correspondence application. 
Starting at now Instagram is the second most standard web put together life mastermind after Facebook. The possibility of Instagram is essential: customers share pictures or accounts instantly after they take photos in the application. Instagram has photo channels which help customers with correcting pictures in the most direct way. Despite Instagram use for photo purpose but it also uses for short video clips of a few seconds in the status to grasp the attention of the followers. Demers Jayson (2017), Kelly David (2016).

\subsection{Twitter}

Twitter is a long range interpersonal communication stage where people post a tweet message inside 140 characters. Tweets can incorporate content, pictures, recordings, and hyperlinks. Rather than being overpowered by composing long messages, Twitter help to express and offer their considerations, thoughts or any writings with 140 characters. Contrasted with numerous Facebook people basically imparting their presents on their companion's no one but, anybody can pursue and convey on public Twitter, which is the reason Twitter is likewise well known for microblogging. Any client can retweet through sharing and answering to others' posts or sending private messages. To get attentionto a particular discussion, people can include hashtags in their posts so different people can join the discussion and it becomes the center of attraction. Kelly David (2016), Jackson Dominique (2017).

\section{Data Collection}

Responses were collected via questionnaire, was adopted one which contains 6 Independent Variable or 1 Dependent Variable, all questions were close-ended having five options, Strongly agree, Strongly disagree,Agree, Disagree, Neutral which was selected by respondent, Total 212 respondent include in the data.

Vlogging, brand promotion, celebrity, consumer buying decision, ethical consideration, and features were measured using Likert scales, 5 items of Appeal, 5 items of brand promotion, 4 items of Celebrity, 4 items of the consumer buying decision, 3 items of ethical consideration, 2 items of features, 3 items of Vlogging.

Table 1. Sample characteristics

\begin{tabular}{lllll}
\hline Variable & \multicolumn{2}{l}{ Category } & Frequency & Percentage \\
\hline Gender & $\bullet$ & Male & 102 & $48.1 \%$ \\
& $\bullet$ & Female & 110 & $51.9 \%$ \\
\hline Age & $\bullet$ & Less than 21 & 16 & $7.5 \%$ \\
& $\bullet$ & $21-30$ & 85 & $40.1 \%$ \\
& $\bullet$ & $31-40$ & 93 & $43.9 \%$ \\
& $\bullet$ & 40 \& above & 18 & $8.5 \%$ \\
\hline Qualification & $\bullet$ & Matric/O-Levels & 2 & $0.9 \%$ \\
& $\bullet$ & Intermediate/A-levels & 37 & $17.5 \%$ \\
& $\bullet$ & Graduate & 104 & $49.1 \%$ \\
& $\bullet$ & Masters & 66 & $31.1 \%$ \\
& $\bullet$ & Doctorate & 3 & $1.4 \%$ \\
\hline Occupation & $\bullet$ & Student & 52 & $24.4 \%$ \\
& $\bullet$ & Workingwomen/ men & 94 & $44.3 \%$ \\
& $\bullet$ & Stay at home & 43 & $20.3 \%$ \\
& $\bullet$ & Self employed & 23 & $10.8 \%$ \\
\hline
\end{tabular}




\section{Ml Macrothink}

The table shows Gender, Age, Qualification and Occupation ratio which help in identify opinion of the respondent. A total 212 responses were collected, among which 102 were male (48.1\%) and 110 were female (51.9\%), the participant were less than 21 (7.5\%), 21-30 $(40.1 \%), 31-40(43.9 \%)$ and $40 \&$ above $(8.5 \%)$. The majority of participant was graduate (49.1\%) University going students, the Master (31.1\%) among them few were those who started their professional life, then some of them college going around (17.5\%) mostly youngster who mostly engage them self in different activities, rest was Matric $(0.9 \%)$ and doctorate $(1.4 \%)$. Most participants were working man/woman (44.3\%) who watch Vlogs, then the student $(24.5 \%)$, few who stay at home (20.3\%) and self-employed were few around $(10.8 \%)$.

\subsection{Appeal}

YouTube is the platform where Vlogger presents their videos, people attracted through discounts on fashionable goods which satisfy their basic need and repurchase it again. The appeals have the tendency to grasp the attention of the people and persuade them to buy.

Table 2 : Shows Mean, standard deviation and variance for Appeal

\begin{tabular}{lllll}
\hline & $\begin{array}{l}\text { Mean } \\
\text { Statistic }\end{array}$ & Std. Error & $\begin{array}{l}\text { Std. Deviation } \\
\text { Statistic }\end{array}$ & $\begin{array}{l}\text { Variance } \\
\text { Statistic }\end{array}$ \\
\hline Youtube & 3.68 & .077 & 1.122 & 1.260 \\
Discounts & 3.53 & .084 & 1.222 & 1.492 \\
Vlogger & 3.67 & .079 & 1.149 & 1.320 \\
Repurchase & 3.83 & .073 & 1.063 & 1.131 \\
Fashionable Good & 3.80 & .075 & 1.098 & 1.205 \\
\hline
\end{tabular}

The table shows mean, standard deviation and Variance, In short, it generates appeals to engage the customer, the mean value lies between $3.53-3.80$, illustrating neutral to agreed responses of the sample respondents for each item.

\subsection{Celebrity}

Celebrity endorsement help in generating desire in the people, through their fame and recognition and many different company advertiser approach Vloggers who are famous to get the audience attention.

Table 3, Shows Mean, standard deviation and variance for celebrity

\begin{tabular}{lllll}
\hline & $\begin{array}{l}\text { Mean } \\
\text { Statistic }\end{array}$ & Std. Error & $\begin{array}{l}\text { Std. Deviation } \\
\text { Statistic }\end{array}$ & $\begin{array}{l}\text { Variance } \\
\text { Statistic }\end{array}$ \\
\hline Endorse & 3.73 & .080 & 1.168 & 1.363 \\
Celebrities & 3.76 & .081 & 1.185 & 1.404 \\
Advertiser & 3.54 & .088 & 1.274 & 1.624 \\
Desire & 3.67 & .080 & 1.158 & 1.341 \\
\hline
\end{tabular}

The table shows mean, standard deviation and variance, In the table shows mean lies between 


\section{Ml Macrothink}

Business and Management Horizons

ISSN 2326-0297

2019, Vol. 7, No. 1

3.54- 3.76 respectively, illustrating neutral to agree responses of the sample respondents for each item.

\subsection{Ethical Consideration}

The problems generated during a brand promotion, Vlogger sort out it with their nice behavior and give respect to the people if someone finds out any difficulty in understanding.

Table 4, Shows Mean, standard deviation and variance for Ethical consideration:

\begin{tabular}{lllll}
\hline & Mean & Std. Deviation & Variance \\
& Statistic & Std. Error & Statistic & Statistic \\
\hline Respect & 4.13 & .068 & .994 & .987 \\
Problems & 3.90 & .078 & 1.129 & 1.275 \\
Brand Promotion & 3.37 & .095 & 1.383 & 1.913 \\
\hline
\end{tabular}

The table shows mean, standard deviation and mean. It represents the mean lies between 3.37 and 4.13 respectively, illustrating neutral to agree on responses of the sample respondent for each item.

\subsection{Features}

Vlogging possesses two most common factor through which people attracted towards them, first the visual communication help in developing the interest secondly; Best rewards provided by the Vlogger the lust of winning free items online via a contest.

Table 5, Shows Mean, standard deviation and variance for features

\begin{tabular}{lllll}
\hline & $\begin{array}{l}\text { Mean } \\
\text { Statistic }\end{array}$ & Std. Error & $\begin{array}{l}\text { Std. Deviation } \\
\text { Statistic }\end{array}$ & $\begin{array}{l}\text { Variance } \\
\text { Statistic }\end{array}$ \\
\hline Best Rewards & 3.52 & .086 & 1.256 & 1.578 \\
Visual & 3.59 & .086 & 1.245 & 1.550 \\
\hline
\end{tabular}

The table shows mean, standard deviation and Variance, In the table above the mean lies between 3.52-3.59 respectively, illustrating neutral to agree on responses of the sample respondent for each item.

\subsection{Vlogging}

Vlogging is a new trend, new product are advertised on a daily bases in which the recommended product is sold out on routine bases. 


\section{Macrothink}

Table 6, Shows Mean, standard deviation and variance for Vlogging

\begin{tabular}{lllll}
\hline & Mean & \multicolumn{3}{c}{ Std. Deviation Variance } \\
& Statistic & Std. Error & Statistic & Statistic \\
\hline Product & 3.72 & .083 & 1.205 & 1.453 \\
Recommended Purchase Product & 3.58 & .086 & 1.250 & 1.562 \\
Advertised & 3.84 & .085 & 1.244 & 1.548 \\
\hline
\end{tabular}

The above table shows mean, Variance and Standard deviation, the table shows above the mean lies between 3.58-3.84 respectively, illustrating neutral to agree responses of the sample respondents for each item.

\subsection{Brand Promotion}

Product promotion helps in generating brand loyalty, for that purpose Vlogger should have an expert in product and possess credibility which helps in generating financial incentive either by their own or through sponsors, The factor brand promotion have the tendency to promote the brand.

Table 7. Shows Mean, standard deviation and variance of Brand Promotion

\begin{tabular}{lllll}
\hline & $\begin{array}{l}\text { Mean } \\
\text { Statistic }\end{array}$ & $\begin{array}{l}\text { Std. Deviation } \\
\text { Std. Error }\end{array}$ & $\begin{array}{l}\text { Variance } \\
\text { Statistic }\end{array}$ \\
\hline Product & 3.72 & .083 & 1.205 & 1.453 \\
Recommended Purchase Product & 3.58 & .086 & 1.250 & 1.562 \\
Advertised & 3.84 & .085 & 1.244 & 1.548 \\
\hline
\end{tabular}

The table shows mean, variance and Standard deviation The value in the table lies between 3.27- 3.44 which is mean, illustrating neutral to agree responses of the sample respondents for each item

\subsection{Consumer Buying Decision}

Consumer buy a product because Vlogger are from modern age generation they provide additional services and offered gifts,most people think they are reliable because they are paid by sponsors, so they offer good quality brand

Table 8. Shows Mean, standard deviation and variance

\begin{tabular}{lllll}
\hline & $\begin{array}{l}\text { Mean } \\
\text { Statistic }\end{array}$ & Std. Error & $\begin{array}{l}\text { Std. Deviation } \\
\text { Statistic }\end{array}$ & $\begin{array}{l}\text { Variance } \\
\text { Statistic }\end{array}$ \\
\hline Modern Age & 3.56 & .087 & 1.270 & 1.613 \\
Additional Services & 3.26 & .089 & 1.294 & 1.674 \\
Paid Sponsored & 3.08 & .093 & 1.350 & 1.824 \\
Giveaways & 3.20 & .090 & 1.314 & 1.726 \\
\hline
\end{tabular}

The above table shows mean, Variance and Standard deviation, in the table the mean lies 


\section{Macrothink}

between 3.08-3.56 respectively, illustrating neutral to agree responses of the sample respondents for each item.

\section{Inferential Statistics}

To measure the impact of factors affecting vlogs and intern brand loyalty and buying decisions, a research instrument having 26 items was used through which an exploratory analysis was conducted. Inferential statistics helps to make inferences and conclusive evidence from the sample data drawn from a population. Exploratory Factor analysis with the help of SPSS is used to reduce a large number of variables to the most important ones Büyüköztürk (2007); Tavşanc1l (2002). Results from the remaining items produced a reliable model and considered for reliability and validity test and path analysis.

\subsection{Reliability Analysis}

Cronbach's alpha is a measure used to assess the reliability, or internal consistency, of a set of scale or test items. In other words, the reliability of any given measurement refers to the extent to which it is a consistent measure of a concept, and Cronbach's alpha is one way of measuring the strength of that consistency.

Reliability Scores $(\mathrm{N}=212)$

Table 9. Reliability test

\begin{tabular}{ll}
\hline & Cronbach alpha \\
\hline Appeals & 0.932 \\
Brand promotion & 0.912 \\
Celebrity & 0.872 \\
Ethical considerations & 0.729 \\
Features & 0.742 \\
\hline Consumer buying decision & 0.788 \\
Vlogging & 0.867 \\
\hline
\end{tabular}

The alpha coefficient for Brand awareness is .932, suggesting that the items have relatively high internal consistency. (Note that the value of the coefficient is .70or higher is considered "acceptable", or less than .07 is moderate, coefficients that are less than 0.5 are usually unacceptable), in the same way,theBrand promotion has 0.912 (acceptable), Celebrity Endorsement has 0.872 (acceptable), Brand loyalty 0.729 (acceptable), Brand building 0.742 (acceptable), Consumer buying decision online 0.788 (acceptable) and Vlogging 0.867 (Acceptable).

Table 10. Reliability statistic

\begin{tabular}{ll}
\hline Cronbach's Alpha & N of Items \\
.800 & 28 \\
\hline
\end{tabular}




\subsection{Exploratory Factor Analysis}

EFA is used when a researcher wants to discover the number of factors influencing variables and to analyze which variables 'go together' DeCoster, (1998). A basic hypothesis of EFA is that there are common 'latent' factors to be discovered in the dataset, and the goal is to find the smallest number of common factors that will account for the correlations McDonald (1985). Another way to look at factor analysis is to call the dependent variables 'surface attributes' and the underlying structures (factors) 'internal attributes' Tucker \& MacCallum(1997) [67].Factor analysis was employed to reduce a large number of variables to extract most underlying variables called factor. Exploratory factor analysis is a useful method to examine the variability among observed variables and excerpt variability from items and load them into a common factor Terre Blanche \& Durrheim (1999). As the study entails exploratory nature, factor analysis was done to identify the most important construct. After the reduction of items, the instrument was reduced to 26 items with 04 items of Appeals, 04 items of Celebrity, 03 items of Ethical consideration, 02 items of features, 03 items of Vlogging, 05 items of brand promotion. Before item reductions, the instrument consisted of 28 items. Buying Behavior comprised of 05 items but only 04 items originally load on its factor and Appeal items replace by the new item of Vlogger. As the study entails exploratory nature, factor analysis was done to identify the most important construct, The value of 'Kaiser-Meyer-Olkin which is the statistical Measure of Sampling Adequacy' (KMO) should be greater than 0.7 Tabachnick \& Fidell (2001) and resultant value --- shows that factor analysis has produced valuable information about the extracted construct. Bartlett's test is used to test if samples are from populations with equal variances. Equal variances across populations are called homoscedasticity or homogeneity of variances. The value of KMO and Bartlett's is 0.774 which is acceptable. This indicates significant value (i.e. 0.000) and confirms reliable results of factor analysis.

Table 11. KMOand Bartlett's test

\begin{tabular}{ll}
\hline Kaiser-Meyer-Olkin (Measure of Sampling Adequacy) & .774 \\
Bartlett's Test of Sphericity (Approx. Chi-Square ) & 3437.8 \\
Df & 325 \\
Sig. & .000 \\
\hline
\end{tabular}

There are three stages in factor analysis:

1. First, a correlation matrix is generated for all the variables. A correlation matrix is a rectangular array of the correlation coefficients of the variables with each other.

2. Second, factors are extracted from the correlation matrix based on the correlation coefficients of the variables.

3. Third, the factors are rotated in order to maximize the relationship between the variables and some of the factors. Zainuddin Awang, Ph.D. (2012) 
Table 12. Rotated component matrix

\begin{tabular}{|c|c|c|c|}
\hline Latent Variable & Item Label & Item Description & $\begin{array}{l}\text { Standardized } \\
\text { Factor } \\
\text { Loading }\end{array}$ \\
\hline \multirow[t]{5}{*}{ APPEALS } & VLOGGER & $\begin{array}{l}\text { Look up product video reviews explained by } \\
\text { Vloggers help in making the decision which is } \\
\text { appealing }\end{array}$ & 0.904 \\
\hline & YOUTUBE & YouTube influence my opinion about the brand & 0.888 \\
\hline & DISCOUNTS & $\begin{array}{l}\text { Discounts and giveaways offered through } \\
\text { Vlogging }\end{array}$ & 0.878 \\
\hline & REPURCHASE & $\begin{array}{l}\text { Consumer repurchase of it fulfill their wants and } \\
\text { needs }\end{array}$ & 0.866 \\
\hline & $\begin{array}{l}\text { FASHIONABLE } \\
\text { GOODS }\end{array}$ & $\begin{array}{l}\text { Rely on Vlogger who sell current and fashionable } \\
\text { or trendy goods }\end{array}$ & 0.814 \\
\hline \multirow[t]{6}{*}{$\begin{array}{l}\text { Brand } \\
\text { promotion }\end{array}$} & BRAND LOYALTY & $\begin{array}{l}\text { Consumer feels intimate relation which increases } \\
\text { brand loyalty }\end{array}$ & 0.899 \\
\hline & $\begin{array}{l}\text { EXPERT IN } \\
\text { PRODUCT }\end{array}$ & $\begin{array}{l}\text { Rely on Vlogger who are expert in the area of } \\
\text { product }\end{array}$ & 0.884 \\
\hline & PRODUCT & Trust the product promotion made by popular & 0.868 \\
\hline & PROMOTION & YouTube Vlogger & \\
\hline & CREDIBILITY & $\begin{array}{l}\text { Consumer buy product after watching Vlog which } \\
\text { increases Vlogger credibility }\end{array}$ & 0.854 \\
\hline & $\begin{array}{l}\text { FINANCIAL } \\
\text { INCENTIVES }\end{array}$ & $\begin{array}{l}\text { Vlogger is less trustworthy as their opinion are } \\
\text { influenced by financial incentives }\end{array}$ & 0781 \\
\hline \multirow[t]{4}{*}{ Celebrity } & ENDORSE & $\begin{array}{l}\text { Celebrity should have required skills and } \\
\text { knowledge which he/she endorse }\end{array}$ & 0.889 \\
\hline & CELEBRITIES & $\begin{array}{l}\text { Celebrities with some sincere and reliable image } \\
\text { are most appreciated }\end{array}$ & 0.850 \\
\hline & ADVERTISER & $\begin{array}{l}\text { Advertiser use celebrities just to manipulate the } \\
\text { mind of the consumer }\end{array}$ & 0.809 \\
\hline & DESIRE & $\begin{array}{l}\text { Consumer feel some degree of desire while they } \\
\text { are purchasing }\end{array}$ & 0.752 \\
\hline \multirow[t]{4}{*}{$\begin{array}{l}\text { Consumer } \\
\text { buying decision }\end{array}$} & MODERN AGE & $\begin{array}{l}\text { Consumer buy product because it is } \\
\text { acknowledged by modern age Vlogger }\end{array}$ & 0.784 \\
\hline & PAID SPONSORED & $\begin{array}{l}\text { Consumer trust vlogger because it is paid or } \\
\text { sponsored by the brand }\end{array}$ & 0.745 \\
\hline & GIVEAWAYS & Consumer buy because Vlogger offer giveaways & 0.713 \\
\hline & $\begin{array}{l}\text { ADDITIONAL } \\
\text { SERVICES }\end{array}$ & $\begin{array}{l}\text { Consumer buy because vlogger provide additional } \\
\text { services }\end{array}$ & 0.721 \\
\hline \multirow{3}{*}{$\begin{array}{l}\text { Ethical } \\
\text { consideration }\end{array}$} & RESPECT & Vlogger who treats with respect is most reliable & 0.813 \\
\hline & PROBLEMS & Vlogger who show concern about my problems & 0.808 \\
\hline & $\begin{array}{l}\text { BRAND } \\
\text { PROMOTION }\end{array}$ & $\begin{array}{l}\text { People don't rely on brand promotion made } \\
\text { through Vlogging }\end{array}$ & 0.758 \\
\hline \multirow[t]{2}{*}{ Features } & BEST REWARD & $\begin{array}{l}\text { Vlogger who has the best reward for loyal } \\
\text { subscriber }\end{array}$ & 0.877 \\
\hline & VISUAL & Words with visual create a greater impact on you & 0.866 \\
\hline \multirow[t]{3}{*}{$\begin{array}{l}\text { The success of } \\
\text { Vlogging(IN) }\end{array}$} & PRODUCT & $\begin{array}{l}\text { People buy a product because Vlogger spoke } \\
\text { about it }\end{array}$ & 0.901 \\
\hline & $\begin{array}{l}\text { RECOMMENDED } \\
\text { PURCHASE } \\
\text { PRODUCT }\end{array}$ & $\begin{array}{l}\text { People purchase product because it is } \\
\text { recommended by the Vlogger }\end{array}$ & 0.873 \\
\hline & ADVERTISED & $\begin{array}{l}\text { People buy a product after seeing it used or } \\
\text { advertised in a video }\end{array}$ & 0.869 \\
\hline
\end{tabular}




\section{Mll Macrothink}

To assess the measurement of the constructs, exploratory factor analysis (EFA) was conducted using the maximum likelihood estimation with rotation. Rotations are either orthogonal, which forces factors to be uncorrelated with each other, or oblique, which leads to freely estimated inter-factor correlations. Despite that the default rotation (i.e., varimax) in popular software (e.g., SPSS and SAS) is orthogonal, the consensus among methodologists is that oblique rotations should be preferred in almost every situationbecause it is unrealistic to expect the constructs that common factors purportedly represent to be perfectly uncorrelated. Orthogonal rotation artificially fixes inter-factor correlations to zero before the question is asked, which can distort interpretations of the factor loadings themselves. The EFA result showed that Purchase decision is to replace by Vlogger which comes under appeals by rotation component matrix. One item is eliminated because it possesses less value than 0.5 by using SPSS.

\subsection{Confirmatory Factor Analysis}

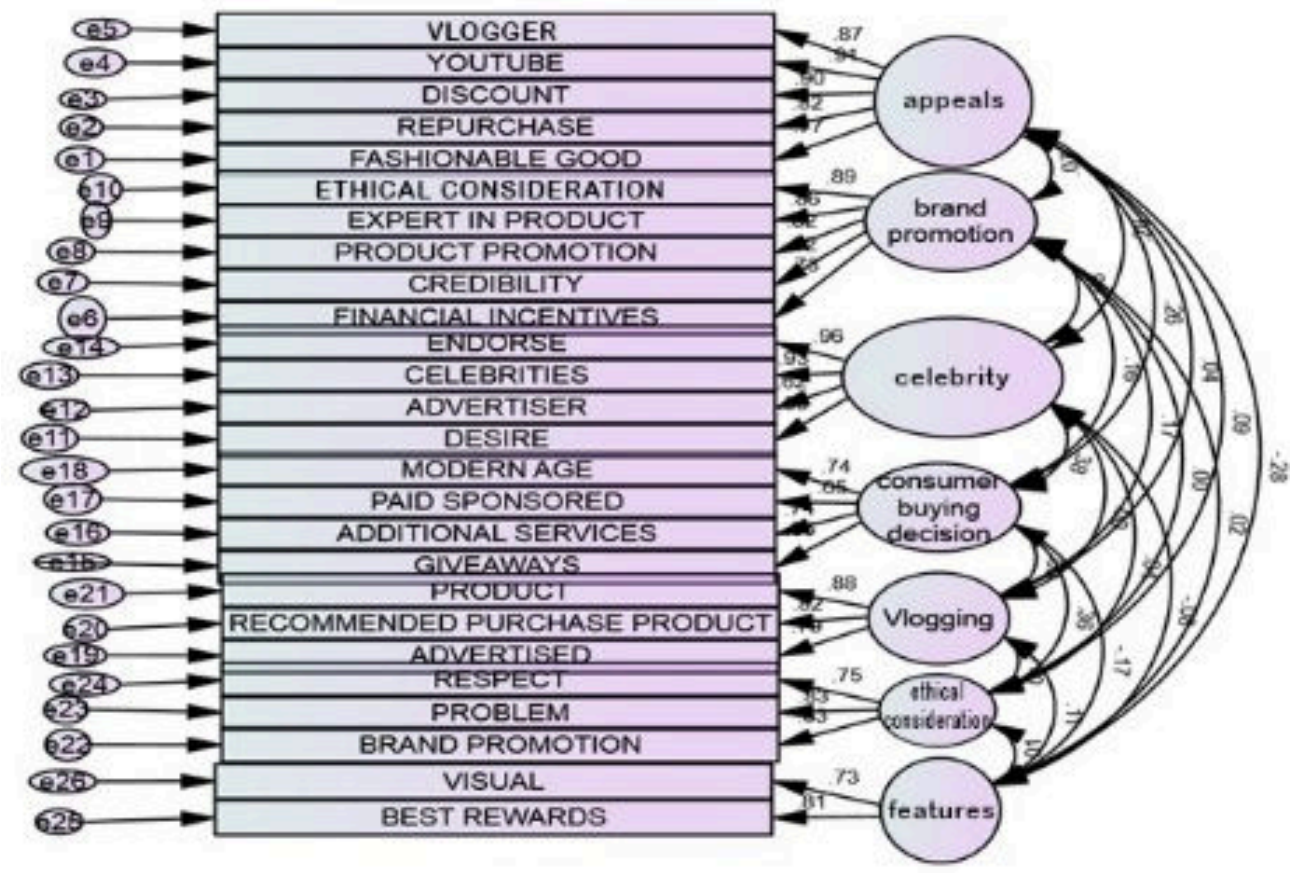

Figure 1. CFA (confirmatory factor analysis) using Amos software, where the relationship between variables is obtained which shows strong co-relation 


\subsection{Confirmatory Factor Analysis Method}

In addition to needing to specify the pattern of fixed factor loadings in CFA, another Distinction between EFA and CFA is that researchers using EFA often do not have a strong hypothesis about the optimal number of common factors, whereas CFA usually does begin with a strong hypothesis about the number of factors. In fact, with EFA, it is still necessary to specify how many factors a model has before it is estimated. Even though CFA is more of a strong hypothesis-testing framework, Methodologists still recommend testing competing models against one another. Finally, model fit Statistics which are usually associated with CFA can also be effectively used in EFA to determine the optimal number of common factors Preacher, Zhang, Kim, \& Mels, (2013).

Confirmatory factor analysis was performed using AMOS. Factor analysis was employed to reduce a large number of variables to extract most underlying variables called factor. Confirmatory factor analysis is a useful method to examine the variability among observed variables and excerpt variability from items and load them into a common factor. The researcher uses knowledge of the theory, empirical research, or both, postulates the relationship pattern a priori and then tests the hypothesis statistically. Diana D (2001).

Table 13. Standardized regression weights

\begin{tabular}{|c|c|c|c|}
\hline Latent Variable & Item Label & Item Description & $\begin{array}{l}\text { Standardized } \\
\text { Factor Loading }\end{array}$ \\
\hline \multirow[t]{5}{*}{ APPEALS } & VLOGGER & $\begin{array}{l}\text { Look up product video reviews explained by } \\
\text { Vloggers help in making the decision which is } \\
\text { appealing }\end{array}$ & 0.87 \\
\hline & YOUTUBE & YouTube influence my opinion about the brand & 0.91 \\
\hline & DISCOUNTS & Discounts and giveaways offered through Vlogging & 0.90 \\
\hline & REPURCHASE & $\begin{array}{l}\text { Consumer repurchase of it fulfill their wants and } \\
\text { needs }\end{array}$ & 0.82 \\
\hline & $\begin{array}{l}\text { FASHIONABLE } \\
\text { GOODS }\end{array}$ & $\begin{array}{l}\text { Rely on Vlogger who sell current and fashionable } \\
\text { or trendy goods }\end{array}$ & 0.77 \\
\hline \multirow[t]{5}{*}{ Brand promotion } & BRAND LOYALTY & $\begin{array}{l}\text { Consumer feels intimate relation which increases } \\
\text { brand loyalty }\end{array}$ & 0.89 \\
\hline & $\begin{array}{l}\text { EXPERT IN } \\
\text { PRODUCT }\end{array}$ & $\begin{array}{l}\text { Rely on Vlogger who are expert in the area of } \\
\text { product }\end{array}$ & 0.86 \\
\hline & $\begin{array}{l}\text { PRODUCT } \\
\text { PROMOTION }\end{array}$ & $\begin{array}{l}\text { Trust the product promotion made by popular } \\
\text { YouTube Vlogger }\end{array}$ & 0.82 \\
\hline & CREDIBILITY & $\begin{array}{l}\text { Consumer buy product after watching Vlog which } \\
\text { increases Vlogger credibility }\end{array}$ & 0.82 \\
\hline & $\begin{array}{l}\text { FINANCIAL } \\
\text { INCENTIVES }\end{array}$ & $\begin{array}{l}\text { Vlogger is less trustworthy as their opinion } \\
\text { influenced by financial incentives }\end{array}$ & 0.73 \\
\hline
\end{tabular}




\begin{tabular}{|c|c|c|c|}
\hline \multirow{6}{*}{ Celebrity } & & Celebrity should have the required skills and & \\
\hline & ENDORSE & knowledge which he/she & 0.96 \\
\hline & & endorse & \\
\hline & CELEBRITIES & $\begin{array}{l}\text { Celebrities with some sincere and reliable image } \\
\text { are most appreciated }\end{array}$ & 0.93 \\
\hline & ADVERTISER & $\begin{array}{l}\text { Advertiser use celebrities just to manipulate the } \\
\text { mind of the consumer }\end{array}$ & 0.62 \\
\hline & DESIRE & $\begin{array}{l}\text { Consumer feel some degree of desire while they } \\
\text { are purchasing }\end{array}$ & 0.59 \\
\hline \multirow[t]{6}{*}{$\begin{array}{l}\text { Consumer } \\
\text { buying decision }\end{array}$} & MODERN AGE & $\begin{array}{l}\text { Consumer buy product because it is acknowledged } \\
\text { by modern age Vlogger }\end{array}$ & 0.74 \\
\hline & ADDITIONAL & Consumer buy because vlogger provide additional & 0.74 \\
\hline & SERVICES & services & \\
\hline & PAID SPONSORED & $\begin{array}{l}\text { Consumer trust vlogger because it is paid or } \\
\text { sponsored by the brand }\end{array}$ & 0.65 \\
\hline & GIVEAWAYS & Consumer buy because Vlogger offer giveaways & 0.65 \\
\hline & RESPECT & Vlogger who treats with respect is most reliable & 0.75 \\
\hline \multirow{3}{*}{$\begin{array}{l}\text { Ethical } \\
\text { Consideration }\end{array}$} & PROBLEMS & Vlogger who show concern about my problems & 0.83 \\
\hline & BRAND & People don't rely on brand promotion made & 053 \\
\hline & PROMOTION & through Vlogging & J \\
\hline \multirow[t]{2}{*}{ Features } & BEST REWARD & $\begin{array}{l}\text { Vlogger who has the best reward for loyal } \\
\text { subscriber }\end{array}$ & 0.81 \\
\hline & VISUAL & Words with visual create a greater impact on you & 0.73 \\
\hline \multirow{5}{*}{$\begin{array}{l}\text { Success of } \\
\text { Vlogging (IN) }\end{array}$} & PRODUCT & People buy product because Vlogger spoke about it & 0.88 \\
\hline & RECOMMENDED & \multirow{3}{*}{$\begin{array}{l}\text { People purchase product because it is } \\
\text { recommended by the Vlogger }\end{array}$} & \\
\hline & PURCHASE & & 0.82 \\
\hline & PRODUCT & & \\
\hline & ADVERTISED & $\begin{array}{l}\text { People buy the product after seeing it used or } \\
\text { advertised in a video }\end{array}$ & 0.79 \\
\hline
\end{tabular}

The measurement model of the latent constructs was also analyzed by confirmatory factor analysis. The measurement model includes seven variables: Appeals, Brand promotion, Celebrity, Consumer buying decision, Ethical consideration, features, and Vlogging. Due to the small standardized factor loading one item is replaced and new one Vlogger take its place because of the rotation matrix and one item of Consumer buying one item replaced by another one.

\subsubsection{Evaluating Measurement Model Fitness}

To evaluate the fitness of the proposed model, Amos delivers a set of useful indices that are used to determine the fitness and validity of the hypothesized model. Out of different significant indices, root means square error of approximation (RMSEA), the goodness of fit index (GFI), Chi-Square, CMIN/DF, adjusted goodness of fit index (AGFI), and comparative 


\section{Macrothink}

Business and Management Horizons

ISSN 2326-0297

2019, Vol. 7, No. 1

fit indices were observed to determine the authenticity of the research model. The discussed indices show the degree to which constructs are related to one another.

Table 14. Model Fitness

\begin{tabular}{lll}
\hline Model Fit & Resultant Value & Threshold \\
\hline CMIN/DF & 2.271 & $<3$ good ; 5 Acceptable \\
CFI & 0.892 & Closer to $1 ;$ good \\
GFI & 0.912 & $>0.90$ \\
AGFI & 0.962 & $>0.80$ \\
RMR & 0.05 & $<0.06$ \\
RMSEA & 0.045 & $<0.05$ \\
PCLOSE & 0.05 & $>0.05$ \\
\hline
\end{tabular}

The measured values of CMIN/DF, CFI, PCLOSE, GFI, RMR, and RMSEA meet the threshold and shows an acceptable model fit. However, the values of AGFI slightly differ from the standard values. The final CFA model fits well to the data.

\subsection{Structural Equation Modeling}

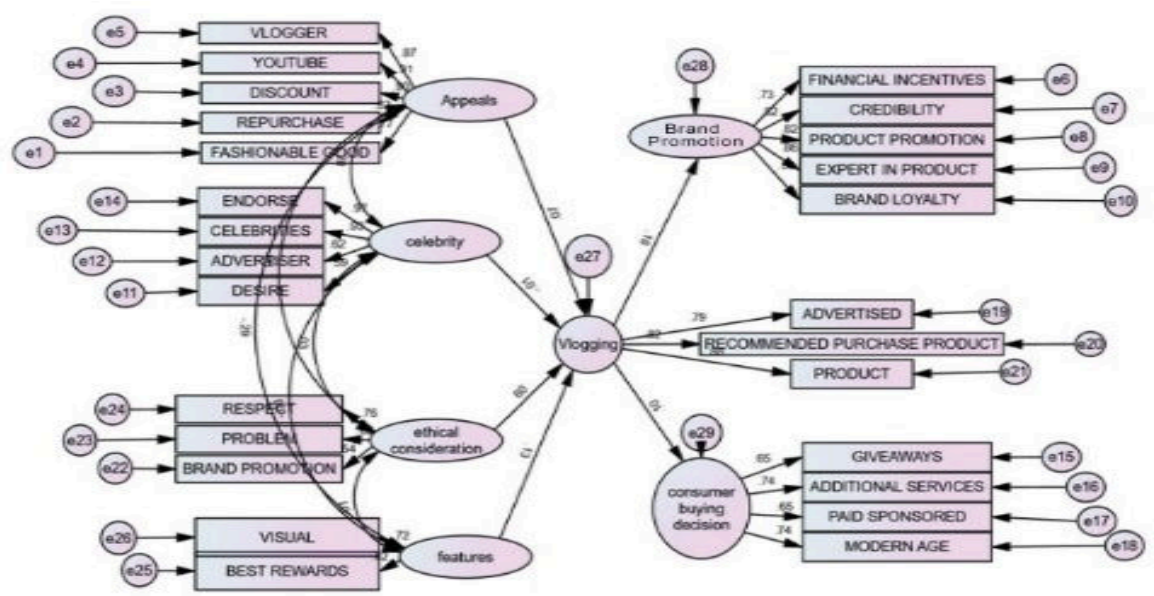

Figure 2. SEM (structural equation model) using AMOS which shows Vlogging use as a dependent and independent variable., Brand promotion and consumer buying dependent on Vlogging

Structural Equation Modeling (SEM) was used to examine the hypotheses. SEM combines both regression analysis and factor analysis. SEM consists of seven major stages, from developing the model, constructing path diagram causal relationship, building and modifying measurement model and finally model fit. A structural equation model consists of an observed variable (OV) and the latent variable (LV). The Relationships between observes and 
latent variables in SEM are shown using a path diagram.SEM integrates both path and factor analyses including multiple observed variables or indicators for every unobserved variable as in factor analysis and specific paths connecting the unobserved variables in path analysis.

Additionally, the concept of utilizing the structural equation model makes sure to apply the bootstrapping technique that has been preferred to be accurate for the sample sizes either large or small. It also does not need any such kind of indirect effects. If the AVE is more than 0.5 than the result is drawn that the loadings are good but less than 0.5 are termed as less effective for the study. In this study, the AVE is greater than 0.5.In order to check the all direct and indirect effects, a technique has been implemented which is known as bootstrapping.

Structural equation modeling used to evaluate the structural relationship between exogenous and endogenous variables. The structural equation modeling includes factor analysis and multivariate analysis of the model. Firstly we evaluate the model fitness and measure whether the paths showing the relationship between measured and latent variables are significant or not. The path diagram showed in figure 3. In this diagram Appeal, celebrity, ethical consideration, and feature represent as Independent variable whereas Vlogging uses as a Dependent or Independent variable,whereas Consumer buying decision and Brand building represent as Dependent variable. The model represents that Consumer buying decision and the Brand building also influence through Vlogging.

Table 15. Model Fitness Test

\begin{tabular}{lll}
\hline Model Fit & Resultant Value & Threshold \\
\hline CMIN/DF & 2.544 & $<3$ good $;<5$ Acceptable \\
CFI & 0.868 & Closer to $1 ;$ good \\
GFI & 0.95 & $>0.90$ \\
AGFI & 0.81 & $>0.80$ \\
RMR & 0.05 & $<0.06$ \\
RMSEA & 0.063 & $<0.05$ \\
PCLOSE & 0.06 & $>0.05$ \\
\hline
\end{tabular}

The goodness of fit is employed to determine the model rejection or acceptance for further analysis. Kline (2005) recommended the four most commonly reported goodness of fit tests are chi-square; Goodness of Fit Index (GFI), Normed Fit Index (NFI),Comparative Fit Index (CFI), and Root Mean Square Error of Approximation (RMSEA). Out of different significant indices, root means square error of approximation (RMSEA), the goodness of fit index (GFI), Chi-Square, CMIN/DF, adjusted goodness of fit index (AGFI), and comparative fit indices were observed to determine the authenticity of the research model. 
Table 16. Regression Weights (Hypothesis Testing)

\begin{tabular}{llllllll}
\hline & & & Estimate & S.E. & C.R. & P & Label \\
\hline Vlogging & $<---$ & Appeals & .015 & .019 & .769 & .442 & par_20 \\
Vlogging & $<--$ & Celebrity & .020 & .024 & .806 & .420 & par_21 \\
Vlogging & $<---$ & $\begin{array}{l}\text { Ethical } \\
\text { considerations }\end{array}$ & 4.434 & 9.462 & .469 & .639 & par_24 \\
Vlogging & $<---$ & Features & .007 & .020 & .342 & .732 & par_25 \\
$\begin{array}{l}\text { Consumer } \\
\text { buying } \\
\text { decision }\end{array}$ & $<--$ & Vlogging & .819 & .559 & 1.466 & .143 & par_22 \\
$\begin{array}{l}\text { Brand } \\
\text { promotion }\end{array}$ & $<--$ & Vlogging & 4.393 & 1.854 & 2.370 & .018 & par_23 \\
\hline
\end{tabular}

The result shows that Appeals has 0.442 level of confidence which means it is acceptable the value with positive values are acceptable which mean that variable has strong bond with each other, the value greater than 0.6 is acceptable with positive values of CR or estimate, in the same way, Celebrity has 0.420 value which is acceptable, Ethical consideration has 0.639, and Features has 0.732. In the second phase when Vlogging become independent variable and consumer buying decision has 0.143 and brand promotion has 0.018 which is highly acceptable where level of confidence is nearer to 0.000 , The above result shows that $\mathrm{H} 1$, $\mathrm{H} 2, \mathrm{H} 3, \mathrm{H} 4, \mathrm{H} 5$, and $\mathrm{H} 6$ hypothesis is acceptable which indicate the model is perfectly accurate and all variables possess a strong relationship with each other.

\section{Discussion and Implications}

Appeal shows 0.442 levels of significance which represent it is accepted because of Appeal made through YouTube, vlogging, through discounts, through fashionable goods which help in the repurchase of product. Celebrity has 0.420 level of significance which is Accepted with the right use of celebrity many products sell out because audience remembers the face of celebrity which helps the companies and even Vlogger to sell out the product as much as they can, Celebrity endorsement right use help in earning more revenue. Ethical consideration has 0.639 level of significance which represent Vlogger popularity lies in the way they show their attitude towards their audience, calm polite and problem solver nature of Vlogger help them in making loyal customer or subscriber. Features has 0.732 level of significance which represent Vlogging features like best rewards and visual play a significant role in attracting a customer, through best reward and for winning purpose subscriber follow the channel of Vloggers for winning the prize through contest, Visual communication help in grasping the attention of the people through body language and attractive images people not hold them back not to watch Vlogs in their spare time. Consumer buying decision has 0.143 level of significance which shows because of Vlogging consumer buying increase and before they buy the product either through online or brick and mortar stores they saw the reviews on social media platform before buying it. The brand promotion has 0.018 level of significance which represent through Vlogging brand promotion or product promotion is quite too easy through a verbal or nonverbal communication medium, which diverts the attention of the audience, Youngster mostly uses vlog to promote their brands and company approach them to 
promote their brands.

One can make their own YouTube channel without any fear of risk associated with it and make their own brand and promote it through YouTube channel easily via looking depth into the product features and associate it with audience accurately. Branding through YouTube also help them to be sponsor by different companies. Many different companies sponsor new and fame Vlogger to promote their channel even they offer them free shopping from their stores and gift them branded items to show in Vlogs through which Vlogger and Company both satisfy each other, Those who love to traveling many companies sponsor their traveling were all accommodations of a Vlogger afford by them. Those who want to earn through Vlog this research help them in the understanding of Branding through Vlogs.

\section{Conclusion}

As evident in these studies, Vlogs are successful in Pakistan because they focus on Celebrities in Vlog help in promoting the brand and generate customer loyalty which triggers to generate more money Via YouTube, Appeals through YouTube grasp the attention of the subscriber, and through features help in engaging the subscriber, Ethical considerations develop respect among the viewers because of the kinds words and polite gesture of YouTuber, Features of Vlogs like visual communication help in generating greater communication through body language and facial expression of the Vlogger which create authentic reviews and people rely on it.

Thus, we can say that with the changing trend in Pakistan Vlogger will make their place in Pakistan and appreciated by a large number of People. If this trend proceeds on in upcoming future nearly more youngster will join YouTube for fame and earning purpose which also helps them in establishing their own business with just a few clicks.

\subsection{Limitations:}

\subsubsection{Strength}

This research will help to understand which factor help in the success of Vlogs, for those who plan out to make their own channel this will help out them to look into the accepted hypothesis and work more on them to run out their own business, it also helps people to trust this new trend because majority of Vlogger is not fake they truly care about their subscriber.

\subsubsection{Weakness}

Firstly, this research is conducted under some parameters, since brand promotion, brand awareness, brand loyalty, brand building not only created on Vlogs there are many other different platforms under which these factors are also measured. Secondly, in this research mostly youngster overview is taken because they engage themselves mostly in social media activities. Thirdly the sample size is quite low so it's not even come under a majority.

\subsubsection{Alternatives}

Study more factors not only from the platform of YouTube but also search out different mediums like snapchat, facebook, Instagram stories / Instagram where Vlogger or common 
person share out videos with a large number of the viewer to sell out the brand to earn money and to entertain people. Secondly, carry out research not only from the youngster but also to the women who do online business on Facebook\&Instagram. Thirdly, the sample size should be increased to gather a largenumber of responses from the people either from a specific area or the overall.

\subsection{Future Research}

Vlogging methods changes with the passage of time, this research focus on 6 factors there will be other factors which were adopted day by day, Future research should take a longitudinal approach to study the more factors which help in the success of Vlogs. Other social media platforms outside of YouTube need investigating.Photo-sharing sites, including Instagram and Snapchat, are a growing platform for would-be the reason for Vlog success. The Accessibility of these platforms and many other platforms make it an interesting context for studying the growth of Vlogs and its success in Pakistan.

\section{References}

Adami, E., \& Jewitt, C. (2016). Special Issue: Social media and the visual. Visual Communication, 15(3), 263-270. https://doi.org/10.1177/1470357216644153

Amos, C., Gary, H., \& David, S. (2008). Exploring the Relationship between Celebrity Endorser Effects and Advertising Effectiveness: A Quantitative Synthesis of Effect Size. International Journal of Advertising, 27(2), 209-234. https://doi.org/10.1080/02650487.2008.11073052

Bandura, A. (2001). Social Cognitive Theory of Mass Communication, Media Psychology (pp. 265-299).

Barnhurst, K. G., \& Quinn, K. (2012). Visual Studies in Political Communication. In H. A. Semetko \& M. Scammell (Eds.), Sage Handbook of Political Communication (pp. 276-291). SAGE Publications. https://doi.org/10.4135/9781446201015.n23

Barnhurst, K. G., Vari, M., \& Rodríguez, Í. (2004). Mapping Visual Studies in Communication. Journal of Communication, 54(4), 616-644. https://doi.org/10.1111/j.1460-2466.2004.tb02648.x

Becker, K. (2006). Where is Visual Culture in Contemporary Theories of Media and Communication. Nordicom Review, 25(1-2), 149-158. https://doi.org/10.1515/nor-2017-0278

Bruce, V. (1996). The role of the face in communication: Implications for videophone design. Interacting with Computers, $\quad 8(2), \quad 166-176$. https://doi.org/10.1016/0953-5438(96)01026-0

Butler, B. (1999). The Dynamics of Cyberspace: Examining and modeling online social structure. Unpublished Ph.D. Thesis, Graduate School of Industrial Administration, Carnegie Mellon University, Pittsburgh, PA. 
Büyüköztürk, Ş. (2007). Data Analysis Manual for the Social Sciences. Ankara: Pegem A. Publishing.

Byrne, Z. S., \& Cropanzano, R. (2001). The history of organizational justice: The founders speak. Justice in the Workplace: From Theory to Practice, 2, 3-26.

Chow, A. (2012). Social Media 247 (pp. 1-49). Singapore: Candid Creation Publishing.

Chown, J., \& Carter, M. (2012). Celebrity endorsement: The trigonometry of talent. Admap, September.

Christodoulides, G. (2009). Branding in the Post-Internet Era. Marketing Theory, 9(1), 141-144. https://doi.org/10.1177/1470593108100071

Cohen, D. (2017). Stats and milestones from Facebook's Q1 2017 financial results. Retrieved May 4, 2017, from http://www.adweek.com/digital/stats-milestones-facebook-q1-2017

Cummings, J., Butler, B., \& Kraut, R. (2002). The quality of online social relationships. Communications of the ACM, 45(7), 103-108. https://doi.org/10.1145/514236.514242

Davison, J., McLean, C., \& Warren, S. (2015). Looking back: ten years of visual quality research. Qualitative Research in Organisations and Management: An International Journal, 10(4), 355-359. https://doi.org/10.1108/QROM-07-2015-1311

DeCoster, J. (1998). Overview of factor analysis. Retrieved March 22, 2012, from http://www.stathelp.com/notes.html

Demers, J. (2017). Why Instagram is the top social platform for engagement (and how to use it). Retrieved March 28, 2917, from https://www.forbes.com/sites/jaysondemers/2017/03/28/why-instagram-is-the-top-social -platform-for-engagement-and-how-to-use-it/\#400ala4436bd

Diana, D. S. (2001). Citing Websites, Exploratory or Confirmatory Factor Analysis.

Elizaveta, Z. (2012). The fight for customers' attention: YouTube as an advertising platform (pp. 83-126).

Ellen, F. (2015). Building brands on YouTube: Communication strategies of three successful beauty vloggers (pp. 36-70).

Evans, R. B. (1988). Production and Creativity in Advertising. London: Pitman Publishing

Fahmy, S., Bock, M. A., \& Wanta, W. (2014). Visual Communication Theory and Research: A Mass Communication Perspective. Basingstoke: Palgrave Macmillan. https://doi.org/10.1057/9781137362155

Falkheimer, J., \& Heide, K. (2014). Participation strategies and social media. In D. R. Holtzhausen \& A. Zerfass (Eds.), The Routledge Handbook of Strategic Communication. London: Routledge

Fatima, S., Muzamil, A., \& Muhammad, T. I. (2014). The Impact of Branding on Consumer 
Buying Behavior. International Journal of Technology and Research, 1.

Fleck, N., Korchia, M., \& LeRoy, I. (2012). Celebrities in advertising: Looking for congruence or likability? Psychology \& Marketing, 29, 651-662. https://doi.org/10.1002/mar.20551

Forbes.com. (2017). The Highest-Paid YouTube Stars 2016: PewDiePie Remains No. 1 With \$15Million. Retrieved March 28, 2017, from https://www.forbes.com/sites/maddieberg/2016/12/05/the-highest-paid-YouTube-stars20 16-pewdiepie-remains-no-1-with-15-million/\#6be2f3477713

Garfield, B. (2006). YouTube vs. Boob Tube. Wired, 14(12).

George, C. (2009). Branding in the post-internet era. Marketing Theory, 9(1), 141-144

Hansen, A. (1998). Analysing Visuals: Still and Moving Images. In Mass communication research methods (pp. 189-224). New York: New York University Press. https://doi.org/10.1007/978-1-349-26485-8_8

Iowenthal, P. (2010). Social presence. In P. Rogers, J. Berg, J. Boettcher, C. Howard, 1. Justice \& K. Schenk (Eds.), Encyclopedia of distance and online learning (2nd ed., pp. 1900-1906). Hershey, PA: Information Science Reference.

Iversen, G. (2009). An ocean of sound and image: YouTube in the context of supermodernity. In P. Snickars \& P. Vonderau (Eds.), The YouTube Reader (pp. 347-357).

Jackson, D. (2017). The complete guide to Twitter marketing. Retrieved October 9, 2017, from https://sproutsocial.com/insights/twitter-marketing/

Jenkins, H. (2006). Convergence culture: where old and new media collide. London, New York: New York University Press.

Keller, K. L. (1993). Conceptualizing, Measuring, and Managing Customer-Based Brand Equity. Journal of Marketing, 57, 1-22. https://doi.org/10.2307/1252054

Kelly, D. (2016). Social media: strategies to mastering your brand-Facebook, Instagram, Twitter, and Snapchat. USA: CreateSpace independent publishing platform.

Khatri. (2006). Celebrity Endorsement: A Strategic Promotion Perspective. Indian Media Studies Journal, 1(1), July-Dec.

Kirill. (2001). The effects of motivation on viewers. Interdisciplinary Journal of Contemporary Research in Business, 2(8), 234-245.

Kotler, P., \& Armstrong, G. (2011, 2013). The principle of marketing (14th ed.). Pearson Education Inc. Prentice Hall.

Kotler, P., \& Keller, K. L. (2016). Marketing Management (15th global ed., pp. 67-80). Harlow: Pearson Education Limited.

Kotler, P., Wong, V., Saunder, J., \& Armstrong, G. (2005). Principle of Marketing (4th 
European ed.). Pearson Education Inc. Prentice Hall

Mabillot, D. (2007). User Generated Content: Web 2.0 Taking the Video Sector by Storm. Communications \& Strategies, 65, 39.

Machin, D. (Ed.) (2014, vol 4). Visual Communication: Handbooks of Communication Science. Boston: De Gruyter.

McDonald, R. P. (1985). Factor analysis and related methods. Hillside, NJ: Lawrence Erlbaum Associates, Inc.

Merriam, W. (1828). Retrieved from https://www.merriam-webster.com/dictionary/appeal

Miles, J. (2014). YouTube marketing power: how to use video to find more prospects, launch your products, and reach a massive audience. New York: McGraw Hill professional.

Miller, M. (2009). YouTube for Business: Online Video Marketing for Any Business (pp. 9-49). USA: Pearson Education.

Miyungi, O., \& Christine, A. (2012). Social Media as a Tool of Marketing and Creating Brand Awareness. Vaasan Ammattikorkeakoulu (Language English Pages $77+2$ Appendices).

Müller, M. G. (2007). What is Visual Communication? Past and Future of an Emerging Field of Communication Research. Studies in Communication Research, 7(2), 7-34.

Müller, M. G. (2008). Visual competence: a new paradigm for studying visuals in the social sciences? Visual Studies, 23(2), 101-112. https://doi.org/10.1080/14725860802276248

Neal, G. (2012). Toward a New Definition of Celebrity (pp. 2-16).

Paul, A., Anderson, M. D., \& Scott, D. B. (2008). Ethical Considerations of Authorship. SAS $J ., 2(3), 155-158$.

Preacher, K. J., Zhang, G., Kim, C., \& Mels, G. (2013) Choosing the Optimal Number of Factors in Exploratory Factor Analysis: A Model Selection Perspective. Multivariate Behavioral Research, 48, 28-56. https://doi.org/10.1080/00273171.2012.710386

Roussel, N., \& Gueddana, S. (2007). beyond 'beyond being there': towards multiscale communication systems (pp. 238-246). Proceedings of the 15th Annual International Conference on Multimedia, September 24-29, Augsburg, Germany. https://doi.org/10.1145/1291233.1291283

Safko, L. (2012). The social media bible: tactics, tools, and strategies for business success. Hoboken, New Jersey: John Wiley \& Sons, inc.

Serrano-Puche, J. (2017). Meta-analysis of Digital Consumption in the Contemporary Media Ecosystem: Key Factors and Emotional Implications. Revista Mediterránea de Comunicación, 8(1), 75-85.

Short, J., Williams, M., \& Christie, B. (1976). The social psychology of telecommunications. 
Toronto: ON John Wiley and Sons

Smith, K. (2016). Marketing: 47 Facebook statistics for 2016. Retrieved October 4, 2016, from https://www.brandwatch.com/blog/47-facebook-statistics-2016/

Solomon, M. R. (2013). Consumer behavior: buying, having and being (p. 639). Harlow: Personal education.

Strangelove, M. (2010). Watching YouTube: extraordinary videos by ordinary people. Toronto: University of Toronto Press.

Svend, H., \& Christian, S. (2013). Selection of celebrity endorsers: A case approach to developing an endorser selection process model. Marketing Intelligence \& Planning, $31(1), 88-102$.

Tabachnick, B. G., \& Fidell, L. S. (2001). Using multivariate statistics. Needham Heights, MA, Allyn \& Bacon.

Tench, R., \& Moreno, A. (2015). Mapping Communication management competencies for European practitioners. ECOPSI an EU study. Journal of Communication Management, 19(1), 39-61. https://doi.org/10.1108/JCOM-11-2013-0078

Terre Blanche, M., \& Durrheim, K. (1999). Social constructionist methods. In M. Terre Blanche \& K. Durrheim (Eds.), Research in practice: Applied methods for the social sciences (pp. 147-177). Cape Town, SA: University of Cape Town Press.

Terre Blanche, M., \& Durrheim, K. (Eds.). (1999). Research in practice: Applied methods for the social sciences. University of Cape Town Press.

Terre Blanche, M., \& Kelly, K. (1999). Interpretive methods. In M. Terre Blanche \& K. Durrheim (Eds.), Research in practice: Applied methods for the social sciences (pp. 123-146). Cape Town, SA: University of Cape Town Press.

Tucker, L. R., \& MacCallum, R. C. (1997). Exploratory factor analysis. Retrieved March 27, 2012, from http://www.unc.edu/ rcm/book/ch7.pdf

YouTube. (2017). PewDiePie. Retrieved March 28, 2017, from https://www.YouTube.com/user/PewDiePie

YouTube. (2017). YouTube for press. Retrieved October 3, 2017, from https://www.YouTube.com/intl/en-GB/yt/about/press/

Zainudin, A. (2012). A handbook on SEM: Structural equation modeling using Amos graphics (p. 61).

Zainudin, A. (2012). Research Methodology and Data Analysis (5th ed., p. 62). Shah Alam: UniversitiTeknologi MARA Publication Centre.

Zainudin, A. (2012). Structural equation modeling using AMOS graphic. Shah Alam: UniversitiTeknologi MARA Publication Centre (UPENA) 


\section{Macrothink}

Business and Management Horizons

ISSN 2326-0297 2019, Vol. 7, No. 1

Zaitceva, E. (2012). The fight for customers' attention: YouTube as an advertising platform.

Zerfass. (2007). Euroblog perspectives on social software in communication management: Results and implications. Leipzig/Luzern/Sunderland. Retrieved from http://www.euroblog2007.org/ euroblog2007-results.pdf

\section{Copyrights}

Copyright for this article is retained by the author(s), with first publication rights granted to the journal.

This is an open-access article distributed under the terms and conditions of the Creative Commons Attribution license (http://creativecommons.org/licenses/by/4.0/). 